\title{
INCOME AVERAGING UNDER THE REVENUE ACT OF 1964
}

\author{
ARTHUR L. GOLDBERG*
}

THE Revenue Act of $1964^{1}$ has amended the Internal Revenue Code of 1954 to provide for a broad income averaging provision. The reason the Administration asked for this sweeping provision was stated by the Secretary of the Treasury:

Under the graduated rate structure of the individual income tax, taxpayers whose incomes fluctuate widely from year to year pay far more in tax than others whose incomes are equal in amount but spread evenly over time. The present law provides averaging relief in certain special cases, but these are complex, varied and narrowly confined. A uniform formula should be adopted which would apply generally to all individuals with widely fluctuating incomes. ${ }^{2}$

The new provision may be used by all taxpayers who have amounts of current "adjusted taxable income" which exceed $1331 / 3$ percent of their average income for the four prior "base period" years. Benefits of the provision are available only if the excess - "averagable income" - is more than $\$ 3,000$. $^{3}$ This provision is available without regard to the type of income received (with, of course, some inevitable exceptions) and without the need to recompute the tax liability of prior years as was necessary under the old law. Essentially the tax is computed by dividing the "averagable income" received in the current year by five, computing the tax on that smaller amount and multiplying the result by five. ${ }^{6}$ Due to the graduated rate structure, the resultant tax will be smaller than if the tax were computed on the full amount. Thus, the basic idea of the new income averaging provisions is to tax "averagable income" in about the same manner as it would have been taxed had it been received rateably over the present and each of the four preceding years. ${ }^{7}$

*Member of the New York Bar.

1. 78 Stat. 19, 105, INT. Rev. Cope $\S \S 1301-05$ (1964).

2. Hearings on the President's 1963 Tat Message Before the House Commitlee on Ways and Meais, 88th Cong, 1st Sess., pt. 1, at 45 (1963) [hereinafter cited as President's Tax Message].

3. INT. Rev. CODE OF 1954, § 1301. [Hereinafter all citations to statutes will be to the INT. REv. CODE OF 1954 unless otherwise noted.]

4. H.R. REP. No. 749, 88th Cong, 2d Sess. 110-11 (1963). [Hereinafter cited as Hoose REPORT. Page numbers preceded by an "A" refer to the Technical Esplanation of the Act; page numbers without the "A" refer to the General Explanation.]

5. Section 1302(a).

6. Section 1301. See Hodse Report 111.

7. House REPORT 110-11. 
Under the provisions of the prior law, 8 repealed by the new averaging provisions, taxpayers were given relief where certain specified kinds of income which were attributable to several years were received in a single tax year. The averaging effect was achieved by computing the tax liability so that the tax burden falling upon the specially treated income items would not exceed the total tax which would have been payable had the income been received rateably over a number of years. ${ }^{9}$ In the case of income derived from eligible back pay, ${ }^{10}$ compensatory damages for patent infringements, ${ }^{11}$ breach of contract or fiduciary duty damages, ${ }^{12}$ damages for injuries under the antitrust laws ${ }^{13}$ and certain professional income derived from "an employment" over a period of years and received in a single year, ${ }^{14}$ the amount received could be "spread back" rateably over the period to which it was attributable. In the case of bunched income received from an invention or artistic work the income could be spread back over the actual period to which it was attributable, but not to exceed a specified number of months. ${ }^{15}$ The result of the old provisions was to put the taxpayer in approximately the position he would have been in had he been able to accrue the income which was subject to relief. The new law abandons most distinctions as to the source of the income and applies the same time period for averaging to all income. Thus, under the new provisions a far greater number of taxpayers will be eligible for relief from bunched income. By adopting across the board averaging the Code makes available averaging relief whenever there is a fluctuation in income, regardless of its cause. ${ }^{10}$ The lump sum receipt need no longer be of such nature that in an accounting sense it was properly attributable to a number of years. This will make relief available in cases where a significant increase in income is due to short term capital gains or other sources attributable solely to a single year. Thus, the new law comes closer to being a true averaging provision. It will also restilt in more favorable treatment of those taxpayers eligible for relief under the old provisions, but who were restricted to a spreadback period of less than five years. Of course, those who would have been able to take advantage of a period

8. Sections 1301-07, immediately prior to the enactment of the Revenue Act of 1964. [Hereinafter these sections will be cited as "Old" sections.]

9. See House RePort 109-10.

10. Old $\S 1303$, originally INT. Rev. Code of 1939, $\S 107$ (d), added by 58 Stat. 39 (1944), and which was carried forth into the 1954 Code by 68A Stat. 335 (1954).

11. Old $\S 1304$, added by 69 Stat. 688 (1955).

12. Old $\S 1305$, added by 71 Stat. 413 (1957).

13. Old $\S 1306$, added by 72 Stat. 1646 (1958).

14. Old $\S 1301$, which was first introduced as $\S 107$ (a), INT. REv. CodE of 1939, as amended, 56 Stat. 837 (1942), and which was carried forth into the 1954 Code by $68 \mathrm{~A}$ Stat. 334 (1954).

Section 232(g) (2) of the Revenue Act of 1964 allows a taxpayer to elect to be taxed under Old $\S 1301$ in certain cases. See House REPORT 110.

15. Old $\S 1302$, which was first introduced as $\S 107$ (b), INr. REv. Cope of 1939, added by 56 Stat. 837 (1942), and which was carried forward in the 1954 Code by $68 \mathrm{~A}$ Stat. 335 (1954).

16. HOUSE REPORT 111. 
greater than five years will be at some disadvantage. ${ }^{17}$ Under the old law it was necessary to recompute the tax liability for previous years, including in income a rateable share of the lump sum item. The tax would then be recomputed at the rates actually prevailing in the spreadback year. ${ }^{18}$ Under the new law the only relevant rate is that in effect in the "computation" year. Since the Revenue Act of 1964 also reduced tax rates significantly, the new provisions on averaging are in this respect certainly more favorable than the old.

The basic theory of the new provisions, however - in permitting averaging only when there has been an increase in income - contains a flaw: it completely ignores the possibility of low income years following high income years, except in the case where income again increases sufficiently to allow the taxpayer to average his income. ${ }^{19} \mathrm{It}$ is true that, as Secretary Dillon pointed out, the total tax paid over a given period of years depends on whether or not the income is received equally over the years or in lump sums. However, the Administration's proposal solved only half the problem (when income increases) and ignored the other side of the coin.

The provisions as enacted introduce several new concepts to the tax law. "Adjusted taxable income" is the taxable income for the computation year, reduced by certain adjustments. "Base period income"21 is the taxable income for each of the four years immediately preceding the computation year - known as "base period years" - again adjusted for certain items. The sum of the "base period incomes" is divided by four to derive "average base period income."22 In general terms, the "adjusted taxable income" of the computation year is compared with the "average base period income." If the former exceeds the latter by $1331 / 3$ percent and if the excess is at least $\$ 3,000$ the taxpayer is eligible for averaging. ${ }^{23}$ To derive "average base period income," the tax-

17. This is because their income is averaged over a shorter number of years with the result that a greater amount of income will be included for each year. See note 14 supro.

18. Old $\S \S 1301-07$.

19. Anthoine, Taz Reduction and Reform: A Lauyer's View, 63 CoLvsr. L. Rev. \&08, 821 (1963); Richman, Incone Averaging - Tax Relief for the High Income $Y_{c a r}, 117$ J. ACCOUNTANCY 37 (1964).

20. Section 1302(b).

21. Section 1302 (c). See note 23 infra.

22. Section $1302(c)$.

23. Section 1301.

The reason for the $\$ 3,000$ de minimis rule and for the requirement that computation year adjusted taxable income exceed average base period income by $1331 / 3$ per cent is stated in the committee report:

Averaging is available only where the "averagable income" exceeds $\$ 3,000$ because, with the present progressive rate structure with tax brackets usually of $\$, 000$ to $\$ 4,000$, smaller amounts achieve little if any benefit from averaging. ... .

Averagable income is limited to that which is in excess of $11 / 3$ times average income in the base period for two basic reasons. First, in any new provision of this type, it is necessary to limit the number of cases to which the new provision will apply to a manageable level from the administrative standpoint. . . Mforeover, it is clear that the greatest need for averaging occurs where the fluctuation in income 
able income of each base period year must first be adjusted by increasing it by an amount equal to income previously excluded as being earned without the United States, or within possessions of the United States, and then decreased by the "capital gain net income" ${ }^{24}$ and any income attributable to property received as a gift within the four "base period" years. ${ }^{25}$

Section 1302(c) (2) states that the base period income of each of the four base period years is "the taxable income for such year first increased and then decreased (but not below zero) in the following order. . . "20 The Code then lists the adjustments mentioned above. ${ }^{27}$ The italicized parenthetical clause in section $1302(\mathrm{c})(2)$ creates a problem of interpretation susceptible to resolution in a manner which might alleviate somewhat the failure of the provisions to provide averaging to relieve declines in income not followed by a rise adequate to trigger the averaging provision.

A first reading of this provision and its legislative history might lead one to assume that, for the purpose of computing the "average base period income," a negative amount may not be included for any of the base period years. This position is supported by the Administration's statement accompanying the President's Tax Message, which states :

A taxable year during which a taxpayer incurs a loss would be included as a zero in determining the prior 4 years' average taxable income.28

However, the technical explanation of the Revenue Act of 1964, as reported by the House Ways and Means Committee, merely states the following:

Paragraph (2) of section 1302(c) provides that an individual's base period income for any taxable year is his taxable income for such year, first increased under subparagraph (A) of such paragraph and then decreased (but not below zero) under subparagraphs (B) and (C) thereof. 20

The parenthetic phrase of section 1302 (c) (2) can reasonably be read to mean that the "base period income" for any "base period year" can not be less than zero only if that result occurs because of the adjustments required by that section. In other words, if taxable income in a base period year is a positive figure, the net result of the required adjustments cannot be such as to bring

levels varies widely. An increase of more than one-third from the prior average income was selected to make the new averaging rule available in those cases where it is needed the most.

HOUSE REPORT 111.

24. Section 1302 (d).

25. Sections 1302 (c) and (e).

26. Section 1302 (c) (2). (Italics àdded.)

27. Sections $1302(\mathrm{c})(2)(A),(B)$, and (C).

28. President's Tax Message 93.

29. House Report A171. The Technical Explanation of the House ReroRt should be given very great weight in the judicial interpretation of the income averaging provisions, as the House version of these provisions was accepted with only three changes by the Senate. Report of the Senate Comattree on Finance to accomspany H.R. 8363, 88th Cong., 1st Sess., Report No: 830, pt. 2, at 262 [hereinafter cited as Sevate Refont]. The Senate changes in no way bore on this part of the averaging provisions. 
the resultant "base period income" below zero. However, if the taxable income before the adjustments is a negative amount, the clause does not apply though presumably the adjustments could not further increase the deficit.

Thus, assuming that the negative amount does not result from the adjustments required by section 1302 (c) (2) (B) \& (C), there seem to be two good reasons why it should be included in the averaging computation. The first is that this result is implied by the technical explanation (quoted above) of the House Ways and Means Committee, which suggests that the statement contained in the President's Message was rejected by the Committee. The second reason is that the theory of the averaging provisions does not require a different answer. While it is true that a taxpayer may not obtain a refund of tax for a year in which no tax was paid, nevertheless the basic idea of the averaging provisions is to tax the income in the current year in approximately the same manner as it would have been taxed had it been received rateably over the full five years. Inclusion of losses in the computation of "average base period income" will realize this result more fully. ${ }^{30}$ The Commissioner has not yet proposed regulations under the new averaging provisions. However, the official forms which have been released for use by taxpayers indicate that he will adopt the position that base period income for any taxable year may not be a negative amount in any situation. ${ }^{302}$ Thus, it is unlikely that the regulations which will be proposed will adopt the suggested reading of section 1302(c)(2) urged here, which is more responsive to the purpose of the provisions.

Generally, long term capital gains and gains under section 1231 are isolated and excluded from the averaging computations. The favorable treatment afforded taxpayers with such gains by other parts of the Code, which in effect provide for a "specialized form of averaging" was thought to require this result." However, for limited purposes capital gains are relevant. "Thus, in determining eligibility for averaging relief capital gains are included in the average taxable income of the prior 4 years and [in] the taxable income for the current year" by the adjustment of section 1302 (a) (2). ${ }^{32}$ That section's effect is to allow determination of eligibility without adjustment of the taxable incomes shown

30. Some individual taxpayers who engage in a trade or business may be able to take advantage of the relief offered by $\$ 172$, which provides for a net operating loss deduction which may be carried back and forward. However, the availability of the benefits of the net operating loss deduction to individuals is greatly limited by $\$ 172(d)(4)$ and in many cases will offer no relief, but, where this section may be invoked, a taxpayer might be able to lessen the rigors of being unable to use negative amounts in computing his "averagable income."

30a. Schedule G, Form 1040 (1964) clearly indicates that it is the Commissioner's contention that a figure of less than zero cannot be used to compute average base period income. See especially, Specific Instructions, Schedule G, Form 1040 (1964) at page 4. As of January 16, 1965 the Commissioner had not proposed regulations under \$\$ 1301-05.

See Schneider, Many Problens Under Income Averaging Unresolved, 22 J. TAxatjon 44, 45 (1965).

31. House Report 113; President's Tax Message 93-94. See note 51 infra.

32. President's Tax Message at 93. 
on the returns. ${ }^{33}$ The President's 1963 Tax Message amply justified this provision:

[I] $\mathrm{n}$ a case in which the taxpayer has in the past received stubstantial amounts of long-term capital gains which are supplanted in the current year by salary or other ordinary income, the taxpayer has not, in fact, had a substantial increase in the amount of income subject to tax at progressive rates. ${ }^{34}$

\section{The Mechanics of Averaging}

\section{(1) Election to use the new provisions}

The use of the new income averaging provisions is optional, and the election to compute the tax under these provisions need not be made on the return itself, but may be made "at any time before the expiration of the period prescribed for making a claim for credit or refund of the tax imposed by this chapter for the taxable year."35 However, if the taxpayer elects to be taxed under these provisions, then the special treatment afforded to income earned from sources without the United States (section 911) and to income from sources within possessions of the United States (sections 931-34) are inapplicable. $^{36}$ The adjustments required to be made once an election is made are

33. The rationale of this provision is explained by an example:

Assume that the taxpayer has income as follows:

Average Base Period Ordinary Income

Average Base Period Capital Gains Net Income

Total Taxable Income (Average)

Computation Year Adjusted Taxable Income Computation Year Capital Gains Net Income

Total Computation Year Taxable Income

Averagable Income:

Computation Year Adjusted Taxable Income

Less: Average Base Period Income

Averagable Income

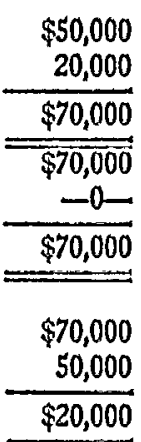

The $\$ 70,000$ "computation year adjusted taxable income" exceeds $1331 / 3$ percent of "average base period income" by more than $\$ 3,000$ and it thus would normally be eligiblo for averaging treatment. Section 1302 (a) (2) requires, however, that "averagable income" be reduced by the excess of average base period capital gain net income $(\$ 20,000)$ over the capital gain net income for the computation year $(\$ 0)$. Thus, in this example, averagable income is reduced to $\$ 0$, and no benefit is had under the new law. The reasonableness of this seems apparent as it is clear that the taxpayer's total economic situation has not been substantially changed, and he has had the advantage of special treatment on his carlier base period capital gains. See notes 77-78 infra and accompanying text.

34. President's Tax Message 94.

35. Section 1304(a).

36. Sections 1304 (b) (3) \& (4). Section 1304(b) (1) states that $\$ 3$ of the Code (relating to the use of the optional tax tables if adjusted gross income is less than $\$ 5,000)$ is inapplicable, and $\S 1304(\mathrm{~b})(2)$ provides that $\S 72(\mathrm{n})$ (2) (relating to the limitation of tax 
solely for the purpose of computing the tax due. ${ }^{37}$

The new income averaging provisions are available to taxpayers for all taxable years beginning after December $31,1963.38$ However, if an individual or partnership accrues compensation from an employment, as defined in section 1301 (b) of the Code as it existed inmediately before the enactment of the Revenue Act of 1964, and the employment began before February 6, 1963, he or it then may elect to apply sections 1301 and 1307 of the Code as in effect immediately before the passage of the 1964 Act. $^{33}$

\section{(2) Who is eligible to use the new averaging provisions}

Generally, "any individual who is a citizen or resident of the United States throughout the computation [present] year"10 and who was not a nonresident alien during any of the four immediately preceding tax years may elect to compute his tax under the new averaging provisions. 11 This provision is intended to assure that the income of an individual, in order to be eligible for averaging, "must have been subject to tax by the United States throughout the entire base period as well as the computation year."42 An additional provision states that "an individual shall not be an eligible individual for the computation year if, for any base period year [any of the four taxable years immediately preceding the computation year], such individual (and his spouse) furnished less than one-half of his support." 13 The "concern of this provision is that the individual be a member of the labor force in both the computation year and in the 4 base period years." 4 It is not intended to exclude a person who "although in the labor force, was unemployed in part or all of the base period years." 45 To attain the desired result a number of exceptions to the general rule have been provided. ${ }^{40}$

in cases of certain distributions with respect to contributions by self-employed individuals) does not apply.

However, $\$ 232$ (c) of the Revenue Act of 1964 amends Code $\$ 144$ to allow an individual electing to be taxed under the income averaging provisions to also elect to take the standard deduction. This is one of the three provisions added by the Senate Sexiate REPORT 262.

37. House RePORT A169.

38. Revenue Act of $1964, \S 232$ (g) (1), 78 Stat. I12.

39. Section 1301(b). See note 14 supra.

40. Section 1303(a).

41. Section 1303 (b).

42. House Report 114.

43. Section 1303(c)(1).

44. HoUSE REPORT 114.

45. Ibid.

46. They are contained in $\$ \S 1303(b)$ and (c). The House Reporr states:

A ... concern of this provision is that the individual be a member of the labor force in both the computation year and in the 4 base period years. It has been necessary, however, to approximate this result in some cases. The general rule provides that the individual and his spouse must have furnished one-half or more of his own support in each of the base period years. However, it was not intended to exclude from the benefits of the averaging provision an individual who, although in 


\section{(3) The averaging computations}

The actual averaging provision is set forth in section 1301 of the Code, which states :

If an eligible individual has averagable income for the computation year, and if the amount of such income exceeds $\$ 3,000$, then the tax imposed by section 1 for the computation year which is attributable to averagable income shall be 5 times the increase in tax under such section which would result from adding 20 percent of such income to the sum of -

(1) $1331 / 3$ percent of average base period income, and

(2) the amount (if any) of the average base period capital gain net income.

After determining that a taxpayer is an "eligible individual,"47 the next step is to ascertain if he has "averagable income" in excess of $\$ 3,000$. To clo this, one starts with the taxable income of the individual for the computation year. The computation year is the current tax year for which the benefits of section 1301 are elected. ${ }^{48}$ To determine the amount of "averagable income," the "adjusted taxable income" of the computation year is compared with the "average base period income." 40 The taxable income of the computation and

the labor force, was unemployed in part or all of the base periad years. For that reason, individuals generally are eligible for averaging if they are 25 years old and there have been at least 4 years since the individual attained age 21 when he was not a full-time student. Thus, generally, individuals age 25 or over will be eligible for averaging so long as they have been out of school for at least 4 years since age 21. A second exception is provided for the individual who, although not selfsupporting in the 4-year base period, nevertheless, has income in the current year more than half of which is attributable in substantial part to work he has done in two or more of the base period years. This is designed to make sure that those who have performed some work of a substantial nature which occurred over a period of years will be eligible for averaging even though below the 25-year age limit. A third exception is provided for an individual who was not self-supporting in the base period and who makes a joint return with someone else if not more than 25 percent of the total adjusted gross income of the couple in the computation year is attributable to the individual in question. This means that an individual who has been in the labor force and who marries someone who was a dependent of another will not be deprived of averaging, assuming three-quarters or more of the income in the computation year is attributable to the individual who was in the labor force in the base period. This is designed to assure that a man who marries a woman who was a dependent of her father during part or all of the base period years is not deprived of income averaging as a result of this marriage.

\section{Id. at 114-15.}

47. Section 1303 defines this term. See notes 40-46 supra and accompanying text.

48. Section 1302 (e) (1).

49. The following is an example of the basic principles of averaging: Assume that our taxpayer is an unmarried individual with a total taxable income of $\$ 12,000$ in the years 1961-1964. In 1965 his salary goes up to $\$ 44,000$. Also assume that he has no income requiring special adjustment. The average base period income is $\$ 3,000$ ( $\$ 12,000$ divided by four); the adjusted taxable income of the computation year is $\$ 44,000$; the avcragable income is $\$ 40,000$ ( $\$ 44,000$ minus $1331 / 3$ percent times the average base period income of $\$ 3,000$, which equals $\$ 4,000)$. Our taxpayer is assumed to be an eligible individual and, 
each of the base period years is subject to adjustments for capital gain net income, income attributable to property received as a gift or by inheritance, income from sources without the United States or from within possessions of the United States, and wagering income. Each of these items will be considered in turn. The resultant amounts will be the "adjusted taxable income" for the computation year, and "base period income," which is really "adjusted taxable income" for each of the base period years. .50

The adjustments follow a logical pattern. First, taxable income of each of the base period years, and of the computation year, is reduced by "capital gain net income" - fifty percent of the excess of net long-term capital gains orer neț short-term capital losses. This amount would include section 1231 gains.51

Secondly, because "income from gifts ... or inheritances ... [which] have been received either in the computation year or in any of the ... base period years ... does not arise from any additional efforts on the part of the taxpayer but merely represents a transfer to the taxpayer of income previously received by someone else,"s2 such income is not eligible for averaging relief. Thus, taxable income of the computation year and of the base period year is reduced by "net income attributable to an interest in property ... received by ... gift ... or inheritance during the computation year or any base period year." Therefore, income attributable to property received as a gift or by inheritance which was received prior to the base period does not require any adjustment. Nor

as his averagable income exceeds $\$ 3,000$, all of his averagable income is subject to averaging. See House Report 113, A170; Senate Report 143.

In order to compute the actual tax liability under the averaging provisions, $\$ 4,000$ (133 $1 / 3$ percent of the average base period income, which is not subject to averaging) is added to $\$ 8,000$ (one-fifth of the averagable income of $\$ 40,000$ ). The tax on $\$ 12,000$ at 1965 rates is $\$ 2,830$. The tax on the $\$ 4,000$ not subject to averaging is $\$ 690$, and therefore the tax attributable to the $\$ 8,000$ of averagable income is $\$ 2,140$. This $\$ 2,140$ is then multiplied by five, for a total tax on the $\$ 40,000$ averagable income of $\$ 10,700$ and, when added to the $\$ 690$ tax on the income not subject to averaging, a total tax liability of $\$ 11,390$ results. The tax on $\$ 44,000$ at 1965 rates without the benefit of the new gveraging provisions would have been $\$ 18,990$, or $\$ 7,600$ more than the tax under the averaging provisions.

50. Section 1302.

51. Sections 1302(b)(1); 1302(c)(2)(B) and 1302(d)(1). Capitad gains need not be subject to averaging since they have, in effect, their own form of averaging inherent in the highly favorable tax treatment afforded taxpayers with such gains. See notes 31-33 supra and accompanying text. Since the taxpayer normally has a great deal of control over the timing of capital gains, if the new provisions were available he could seriously distort his income solely for purposes of taking maximum advantage of the averaging provisions. See SeNATE REPORT 142. Section 1231(a) states that transactions that qualify under that section are to "be considered as gains and losses from sales or exchanges of capital assets held for more than 6 months." A transaction so labelled is a "long-term capital gain or loss" by definition, under $\S \S 1222(3)$ and (4), and the net gain is a "net long-term capital gain" under $\S 1222(7)$. The $\$ 1231$ gain finally enters the averaging computation vis the use of the phrase "net long-term capital gain" in $\$ 1302$ (d) (1). It should be noted, however, that the committee reports are silent on this particular point.

52. House RePort 112.

53. Sections $1302(b)(2) ; 1302(c)(2)(C)$. 
does the adjustment apply to "gifts ... or inheritances between [a] husband and wife if they make a joint return, or if one of them makes a return as a surviving spouse ... for the computation year." ${ }^{\text {"54 }}$ Unless the taxpayer can establish otherwise, the income is imputed at the rate of six percent of the value of the property for estate or gift tax purposes (unadjusted for subsequent changes in value).$^{55}$ However, if the amount of such income does not exceed $\$ 3,000$ in the computation year, then no adjustment is required in the computation or any of the base period years. ${ }^{50}$ If the amount of such income in the computation year does exceed $\$ 3,000$, then adjustments are required in the computation year and in each base period year, even if the amount of the adjustment in the base period does not exceed $\$ 3,000.57$

The committee reports imply that the property received by gift or inheritance must be "income producing" for the adjustment to apply, ${ }^{, 8}$ though the statute's broad language could be read to apply to any property. ${ }^{60}$ Clearly the reports' construction should prevail, otherwise income could be attributed to property which is used by the taxpayer (such as a gift of jewelry, a car or a home used as a residence) and not put to earning income. While this type of factual pattern is not mentioned in any of the committee reports, section 1302 (b) (2) (B), which states that the property is deemed to earn six percent of the gift or estate tax value unless the taxpayer can establish to the contrary, should prevent the Treasury from proposing an adjustment in this type of a situation. Presumabiy, the income reported on a tax return accepted by the Internal Revenue Service should suffice to establish the income of such property for the purpose of this adjustment.

A situation that is not covered in the reports is one where the donated or inherited property is sold. It would seem that the proceeds from disposition should be treated as if they came from property received by gift or inheritance, in order to prevent avoidance of the requirement to reduce computation year income. This rule, then, would be another factor to consider in deciding what property should be donated in kind to charity, for clearly, the income on "gift" property which is given away during a year in a bona fide completed transaction is not subject to adjustment. However, an adjustment would be required to the extent of income on the donated property which accrued to the taxpayer during the period prior to the date of the donation, if either alone or in combination with other property it earned over $\$ 3,000$ for the taxpayer in the computation year. While the argument made in the committee reports that income from donated or inherited property is not earned is valid, nevertheless the required adjustment penalizes the donee or legatee, when (prestumably) income from the very same property (or interest in property) would have
54. Section 1302(b) (2)(A).
55. Section 1302 (b) (2) (B).
56. Section 1302 (b) (2) (C).
57. Sections 1302 (b) (2) and 1302 (c) (2) (C).
58. House Report 112; Senate Report 142.
59. Section 1302(b) (2) (A). 
qualified for averaging in the hands of the donor or deceased. A further penalty is imposed where the donee or legatee increases the income yield of the property through his own efforts. In this case, such income may not be averaged until the year of the receipt of the property no longer falls within the base period. ${ }^{60}$ In addition, the argument that this adjustment prevents "manipulation" is not valid, since a high-bracket taxpayer can give income-producing property to a low-bracket taxpayer at any time, so long as the transaction is a legally binding one and so long as the tree follows the fruit. ${ }^{01}$ If a highbracket taxpayer chooses to give income-producing property (with no strings attached) to a low-bracket taxpayer, the rules governing eligible individuals would limit his choice of a donee only if the tax effect under the averaging provisions were his prime motive.

The next adjustment is the increase of taxable income of any base period year when any income in that year was excluded from gross income, under sections 911 and 931-934, on the ground that it was earned from sources without the United States or from within possessions of the United States. ${ }^{\circ 2}$ This is required in order to prevent the taxpayer from receiving the double benefit of excluding income and computing his tax under the averaging provisions based on the lower gross income. Since the foreign income exclusions may not be used for a computation year when a taxpayer elects to average his income, ${ }^{63}$ this adjustment to "base period income" is required to make the income of the base period comparable to that of the computation year.

Finally, the taxable income of the computation year is reduced by net wagering income and certain other income which is subject to a penalty tax.os This is done in order "to prevent such income from receiving a preferred status." 65 It should be noted, however, that no similar reduction is made to the taxable income of any base period year, ${ }^{86}$ and therefore the taxpayer with these types of income is at a double disadvantage, as the higher his base period income the lower will be his averagable income.

60. Ibid. Another striking effect of this provision is that income in respect of a decedent, taxable under $\S 691$ of the Code, falls into the very broad range of things corered by the phrase "net income attributable to an interest in property" as used in the House Report. HOUSE REPORT A169-70. While it could be argued that in the case where the only interest is the income itself, its receipt should not necessitate an adjustment, nevertheless it seems that an "income interest" in the property is still "an interest," and therefore an exception could not be made by regulation or judicial decision so as to exclude $\S 691$ income.

61. Cf. Lucas v. Earl, 281 U.S. 111, 115 (1930).

62. Section 1302 (c) (2) (A).

63. Sections 1304 (b) (3) \& (4).

64. Sections 1302 (b) (3) \& (4). It should be noted that the fact that the wagering transaction is not illegal under state law is immaterial for this purpose. If it is desired to use the tax laws to enforce a social policy, it does not seem appropriate to penalize a transaction for tax purposes when the state has seen fit to give full legal status to that very same transaction. And see note 76 infra.

65. House RepoRT 112.

66. See $\$ 1302(c)$. 


\section{(4) Order of taxing various types of income}

Perhaps the most intricate and obscure of the new provisions are those setting forth the order in which the various types of income are to be talken into account in determining the computation year tax liability. ${ }^{07}$ Since the taxpayer need not actually go back and recompute his tax in each base period year, Congress made an effort to tax each type of income in the computation year as nearly as possible in the same manner as it would have been taxed had it been taxed in a base period year. ${ }^{.8}$

The first level of income (which is therefore taxed at the lowest rate) is an amount equal to $1331 / 3$ percent of the average base period income. ${ }^{00}$ This amount is not subject to averaging at all. The next level is comprised of the excess of the average base period capital gain net income over that of the computation year. ${ }^{70}$ If the capital gain net income of the computation year exceeds the average base period capital gain net income, then an amount equal to the computation year capital gain net income (but not exceeding the average base period capital gain net income) is taxed at the third level. ${ }^{71}$ However, if in any base period year the base period capital gain net income exceeds the base period income computed without regard to the requirement of deducting the capital gain net income for that year, then, for this purpose, the capital gain net income of that base period year is limited to the base period income of that year. ${ }^{72}$

The fourth level of income is composed of twenty percent of the averagable income. The amount of the tax attributable to one-fifth of the averagable income at this level is then multiplied by five in order to determine the full tax attributable to the income subject to averaging - the averagable income. ${ }^{73}$ This level would include Subchapter $S^{74}$ income; in fact, the averaging provisions might be a reason to elect to be taxed under Subchapter $S$, as the benefits of averaging could thereby be extended to corporate income not generally eligible for such treatment. ${ }^{74 a}$ The fifth level consists of income from property

67. Sections $1301,1304(\mathrm{e}),(\mathrm{f})$ and $(\mathrm{g})$.

68. Sections 1304(e), (f) and (g); House Report 113, A179; SENATE Report 143.

69. Cf. $\$ 1304(\mathrm{e})(1)(\mathrm{A})$; House REPORT A179.

70. Section 1304 (e) (1). See House Report A179.

71. Section 1304(e)(1).

72. Section 1302(d) (2); House REFORT A172. It should be noted that the average base period capital gain net income is taxed before averagable income, therefore increasing the tax on averagable income.

This rule applies even if the long-term gains during the base period were subjected to the alternative tax. It seems unfair to use prior capital gains to increase the tax on averageable income, while at the same time excluding current capital gains (even though not subject to the alternative tax) from the averaging privilege.

Comments, Committee on Federal Taxation, American Institute of Certified Public Accountants, Hearings Before the Senate Committee on Fintance on the Revemuc Act of 1963 [1964], 88th Cong., 1st Sess., pt. 5, at 2430.

73. Section 1301.

74. Sections 1371-77.

74a. Also includible is ordinary income on the sale or redemption of $\& 306$ preferred stock or stock in a collapsible corporation, recaptured income under $\$ \$ 1245$ or 1250 , pension or profit-sharing plan distributions treated as ordinary income and net short-term capital gains. See Schneider, Many Problems Under Income Averaging, 22 J. TAXAт10N 44 (1965). 
received as a gift or inheritance and income from wagering transactions. The sixth level is made up of the excess (if any) of the computation year capital gain net income over the average base period capital gain net income (see level three)..$^{75}$ Finally, the tax attributable to certain amounts of "penalty" income received by owner-employees is added at the seventh level. ${ }^{70}$

75. Section 1304(e)(1) (B).

76. Section 1304(f)(2). There is at least one type of "penalty" income that could be taxed at level four as normal averagable income. It is the income created by $\S 422$ (c) (1) of the Code. This section concerns the issuance of a qualified stock option at less than the fair market value of the stock when the option was granted. Under this provision, the employee may have to report 150 percent of the difference between the option price and the fair market value of the stock when the option was granted as ordinary income. Clearly, this extra fifty percent is a penalty. The Secretary of the Treasury may attempt to create an eighth level, under authority of $\S 1304(f)(3)$, to include this kind of "penalty" income. There is no specific authority in the history of the act to sanction this, but as it would be not too unlike level seven income $(\S 1304(f)(2)$ ) the regulation might survive judicial scrutiny.

An example illustrating the rules discussed in the text follows. The figures are those used in the House REPORT at A180. Hopefully, however, the method of presentation has been clarified:

\begin{tabular}{lccccc} 
& & \multicolumn{3}{c}{ Types of Income } \\
\cline { 5 - 6 } Year & Taxable Income & & Salary & Gift Income & $\frac{\text { L.T. Cap. Gains }}{$\cline { 5 - 6 }} \\
\cline { 5 - 6 } 1960 & $\$ 8,250$ & $\$ 2,000$ & - & $\$ 12,500$ \\
1961 & 7,750 & & 4,000 & - & 7,500 \\
1962 & 7,500 & & 3,500 & - & 8,000 \\
1963 & 8,500 & & 2,500 & - & 12,000 \\
1964 & 59,000 & 44,000 & $\$ 5,000$ & 20,000
\end{tabular}

There being no "gift" or "inheritance" or other income requiring adjustment, the average base period income is:
1960
1961
$\$ 2,000$
1962
4,000
1963
Total
Average Base Period Income

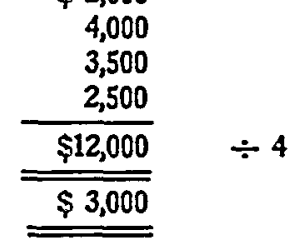

The average base period capital gain net income is computed as follows:

$\begin{array}{lrlll}1960 & \$ 12,500 \text { at } 50 \% & = & \$ 6,250 \\ 1961 & 7,500 \text { at } " & = & 3,750 \\ 1962 & 8,000 \text { at } " & = & 4,000 \\ 1963 \quad 12,000 \text { at } " & =\frac{6,000}{\$ 20,000} \\ & \text { Total } & & \underline{\$ 5,000}\end{array}$

The averagable income for 1964 is computed as follows:

Taxable income - 1964

Less:

Capital gain net income

$(\$ 20,000 \times 50 \%)$

Income from property received as a gift

(Continued os page 478) 
(Footnote 76 continued)

Adjusted taxable income

Less :

$1331 / 3$ percent of average base period income

$\frac{4,000}{\$ 40,000}$

Averagable income

Thus, with all of our basic figures computed, we can now proceed to compute the tax liability of our unmarried taxpayer in accordance with the various levels of taxation outlined above.

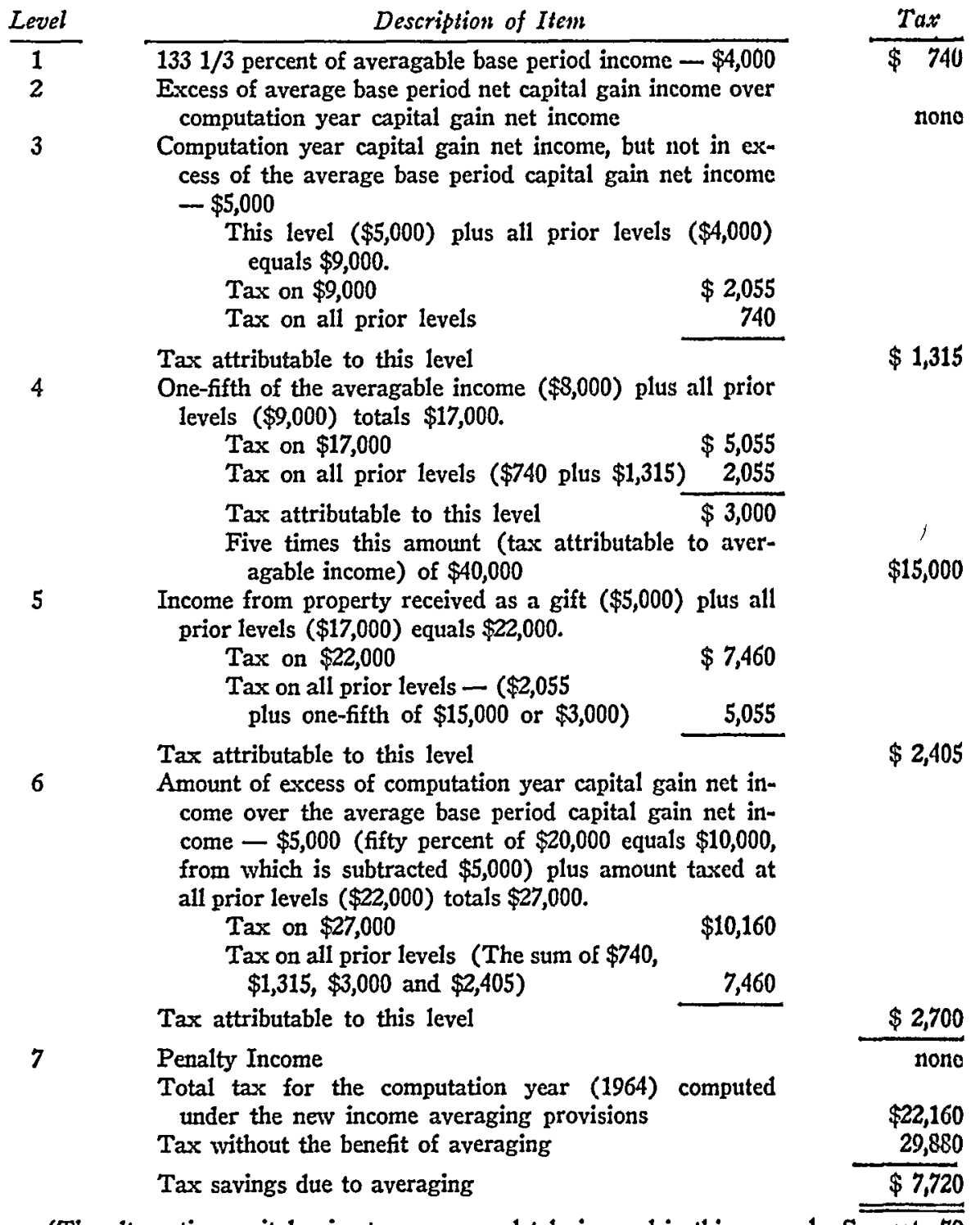

(The alternative capital gains tax was completely ignored in this example. Sec note 79 infra for an example using the alternative capital gains tax.) 


\section{(5) Adjustments for capital gains in certain cases}

Section $1302(a)(2)$ provides that if the average base period capital gain net income exceeds that of the computation year, the amount of the excess must be deducted from the amount that would otherwise constitute averagable income. Therefore, all other factors being equal, it will be advantageous to realize capital gain net income in the computation year to the full extent of the average base period capital gain net income. Failure to do this will result in a reduction in averagable income. The purpose of this provision is to insure "that averaging [is] . . . permitted only when total taxable income of the current year is substantially greater than the average of the base period."77 Thus a mere change in source of income will not trigger the availability of the new averaging provisions. ${ }^{78}$ The benefits of the alternative capital gains tax (section 1201(b)) are preserved by section 1304(e) (2) which basically provides that the tax attributable to computation year capital gain net income shall not exceed the alternative tax. ${ }^{79}$

77. House Repozt 113. (Italics added.) See also note 33 supro.

78. See notes 31-33 stpra and accompanying text.

79. Senate Report 144.

In the following illustrative example all of the previous data (see note 76 sipra) for the base period years remain unchanged. In 1964, our taxpayer has $\$ 44,000$ of income from wages and an $\$ 80,000$ long-term capital gain. The tax would be computed as follows:

\begin{tabular}{|c|c|c|c|}
\hline Level & \multicolumn{2}{|l|}{ Description of Item } & Tar \\
\hline $\mathbf{1}$ & \multicolumn{2}{|c|}{$1331 / 3$ percent of average base period income $-\$ 4,000$} & $\$ 740$ \\
\hline 2 & \multicolumn{2}{|c|}{$\begin{array}{l}\text { Excess of average base period capital gain net income } \\
\text { over computation year capital gain net income }\end{array}$} & none \\
\hline \multirow[t]{2}{*}{3} & \multicolumn{2}{|c|}{$\begin{array}{l}\text { Computation year capital gain net income, not exceeding } \\
\text { average base period capital gain net income }-\$ 5,000 \text {. } \\
\text { Taxed in prior levels } \$ \$, 000 \text {, equals } \$ 9,000 \text {. }\end{array}$} & \\
\hline & Tax attributable to this level & & $\$ 1,315$ \\
\hline \multirow[t]{2}{*}{4} & \multicolumn{2}{|c|}{$\begin{array}{l}\text { One-fifth of averagable income }(\$ 8,000) \text { plus amounts } \\
\text { taxed at prior levels }(\$ 9,000) \text { equals } \$ 17,000 \text {. } \\
\text { Tax on } \$ 17,000 \\
\text { Tax on all prior levels }\end{array}$} & \\
\hline & $\begin{array}{l}\text { Tax attributable to } \$ 8,000 \\
\text { Tax attributable to } \$ 40,000\end{array}$ & $\$ 3,000$ & $\$ 15,000$ \\
\hline $\begin{array}{l}5 \\
6\end{array}$ & \multicolumn{2}{|c|}{$\begin{array}{l}\text { Income from property received as a gift. } \\
\text { Computation year capital gain net income in excess of } \\
\text { average base period capital gain net income }(\$ 35,000) \\
\text { plus amounts taxed at all prior levels }(\$ 17,000) \text { equals } \\
\$ 52,000 \text {. }\end{array}$} & none \\
\hline & Tax attributable to this level & & $\$ 20,205$ \\
\hline
\end{tabular}

(Continued on page 480) 
(6) Problems posed when the taxpayer changes and with joint returns

Section 1304(c) requires special adjustments to be made to base period income when the taxpayer in the computation year is not the taxpayer in ench of the base period years. ${ }^{80}$ This situation arises when a joint return is filed for the computation year and separate returns were filed in one or more base period years, or when joint returns were filed in all base period years but the taxpayer's spouse has changed. Conversely, adjustments would be required if a separate return were to be filed in the computation year and a joint return was filed for any base period year.

The simplest case is where a joint return is filed for the computation year and a separate return was filed for one or more base period years, during which the parties were not married. In this case, the base period income of the now-married taxpayers would simply be the total of their separate incomes for each base period year. Community property rules are ignored if a joint return is filed in the computation year. ${ }^{81}$

If an individual was married in any base period year and is not married in the computation year, his base period income is the greater of his actual base period income or fifty percent of the base period income computed on a joint return basis, whether or not a joint return was in fact filed. If an individual is married to a spouse different from the one in any base period year, then the result of the above computation is compared with fifty percent of the base period income based on a joint return for that base period year, as if one had been filed by the taxpayer and his spouse of the computation year. That is, a comparison is made between the individual's own base period income and fifty percent of the base period income based on the filing of joint returns by him and his former and present spouses. The greater of the three amounts is the base period income of such individual for the computation year calculation. ${ }^{82}$ If the above adjustment must be made by a taxpayer, then he must also

(Footnote 79 continued)

$\frac{\text { Level }}{7}$

Description of Item
$\begin{aligned} & \text { Penalty income. } \\ & \text { Tax after averaging but before computation of the alter- } \\ & \text { native tax }\end{aligned}$

Computation of the alternative tax is as follows:

Tax attributable to level 3

Tax attributable to level 6

Total tax attributable to capital gain net income of the computation year $\$ 21,520$

Alternative tax - $25 \%$ of $\$ 80,000$

20,000

Savings

$\$ 1,520$

Tax after averaging but before use of alternative tax

Tax after averaging and use of the alternative capital gains tax

37,260

Tax without averaging but with the alternative capital gains tax

$\$ 35,740$

40,130

Savings due to averaging

$\$ 4,390$

80. See President's Tax Message 95; House RepoRT 115.

81. Section 1304(c) (1) (B).

82. Section 1304(c) (2). 
recompute his capital gain net income for any affected base period year in an identical manner. ${ }^{83}$ If the above adjustments apply, each spouse must make them separately, since each spouse is considered separately for this purpose.84

In the event that a joint return is filed in the computation year, the $\$ 3,000$ basic limit in computing averagable income contained in section 1301, and the $\$ 3,000$ floor relating to adjustments due to income from property recerved by gift or inheritance, are applied to the aggregate incomes on the joint return. ${ }^{85}$

\section{ConcLusion}

The Code's new averaging provisions can be expected to afford relief to a substantial number of taxpayers who were not eligible under the old law. However, the law's benefits are generally available only to taxpayers who have experienced sharp rises in income. Those who suffer equally pronounced declines in income, and who seem equally deserving of relief, will likely not be able to avail themselves of the benefits of the Code. Other methods of averaging have been suggested, ${ }^{86}$ and the major justification for the particular method chosen by Congress is the alleged simplicity and ease of administration which the new provisions would make possible. ${ }^{87}$ It seems unlikely that the new provisions will in fact fulfill Secretary Dillon's expectation that it "would achieve substantial simplification of this part of the tax law." Some of the computations required to determine the tax liability are probably more involved than those required by the old law. Further study should be given to the desirability and practicality of additional modification of the averaging seetions with the view toward providing a "true averaging" provision available to all taxpayers who experience substantial fluctuations in income.

83. Section 1304(c) (3); House Report A177.

84. HOUSE REPORT A177. The result of these adjustments is that the same income may be used twice in computing base period income, thereby reducing the benefits of averaging. In fact, the requirement of using the larger of the taxpayer's own base period income or fifty percent of the base period income computed on a joint return basis with the taxpaycr's former and present spouse seems to indicate that Congress was either trying to discourage divorce or prevent a taxpayer from divorcing one spouse and marrying another simply to gain an advantage under the averaging provisions. Either theory is ludicrous. In the interests of both fairness and simplicity, an individual should only have to include his own actral income in computing his base income period in this type of a situation.

85. Section $1304(d)$.

86. See, e.g., Bravman, Equalization of Tax on All Individuals with the Same Aggregate Income Over Same Number of Years, 50 Cosuar. L. Rev. 1 (1950); see generally House Committee on Ways and Means, 1 Tax Revision Cosrpendrusr 579-673 (1959).

87. House Report 110.

88. President's Tax Message 89. 


\section{THE YALE LAW JOURNAL}

VoLUMe 74

JANUARY 1965

NUMBER 3

RICHARD AdaMrS

JOHN R. ADLER

Jonathan A. Ater

Richard J. Braemrer

DENNIS $K$. BROMLEY

E. Edward Bruce

Míchael A. Brush

Charles N. Burger

Robert A. Carter

Rayaiond C. Clevenger, III

Dennis E. CuRtis

Anthony A. Dean

Walter E. Deuringer, III

W. LeE H. DunhaM

Roger D. FetDMaAN

JAMES T. B. Tripp

Business Manager
Charues M. Nathan

Editor-in-Chief

\author{
Danier Marcus \\ Topics Editor \\ Ceaprees Donatue, Jr. \\ SHerwin M. Goldusan \\ Article \& Book \\ Revicw Editors
}

MarTIN E. Low

Managing Editor

Gregory C. GlynN

JAMRES S. GordoN

Michaed F. Hatioran

B. BOYD Hrght, JR.

C. Stephen Howard

Grorge L. Jurow

Howard A. KNight

Martin D. KRali

Simon Lazarus, III

Bersx LeVTN

RONALD F. LIPP

Cameron F. MacRae, III

Fredertck B. MCLANE

Rod MCMaHaN

Leonand M. Manks

Anita S. Marthi

barbara H. Paul

Edward A. Perrell

David A. Ramas

LEONARD M. Ross

Fred E. SCHARF

Benno C. Schamid, Jt.

LARRY G. SiMON

LEONAND P. Strterisan

Willard B. TAYlor

Mrcirael S. WALt

Maris A. Walteer

ROdert F. WALTER

Peter L. Zturotir

Bella Seidendaum

Business Secrelary

\section{CONTRIBUTORS TO THIS ISSUE}

Howard P. Finx. B.S. 1955, Cornell University; LL.B. 1958, Yale University.

Kurt H. NADELMaNN. J.U.D. 1921, Freiburg University.

Arthur L. Goldberg. B.A. 1959, City College of New York; LL.B. 1962, New York University.

Rodert M. Dudnik. B.A. 1960, Cornell University; LL.B. 1964, Yale University.

Jon R. WALtz. B.A. 1951, College of Wooster; LL.B. 1954, Yale University.

JohN M. DE Grove. A.B. 1953, Rollins College; M.A. 1954, Emory University; Ph.1. 1958, University of North Carolina.

LAWRence M. Friedaran. A.B. 1948, J.D. 1951, M.LL. 1953, University of Chicago. 